\title{
Penggunaan Media Pembelajaran Berbasis Visual dalam Meningkatkan Berpikir Kritis Siswa pada Pelajaran Matematika
}

\author{
Nikmatul Khoiriyah ${ }^{\mathbf{1}}$, Adityawarman Hidayat ${ }^{\mathbf{2}}$, Fadhilaturrahmi $^{\mathbf{3}}$ \\ (Pendidikan Guru Sekolah Dasar, Universitas Pahlawan Tuanku Tambusai, Indonesia) \\ * Corresponding Author. E-mail: 1nikmatulkhoiriyah393@gmail.com,
}

\begin{abstract}
Abstrak
Penelitian ini bertujuan untuk mengetahui penggunaan media pembelajaran berbasis visual dalam meningkatkan kemampuan berpikir kritis siswa pada mata pelajaran Matematika di kelas IV SDN 032 Kualu. Metode yang digunakan pada penelitian ini adalah Penelitian Tindakan Kelas (PTK). PTK yang dilaksanakan terjadi dalam dua siklus. Setiap siklus menggunakan empat tahap antara lain: tahap perencanaan, tahap pelaksanaan, tahap observasi dan refleksi. Subyek penelitian ini adalah siswa kelas IV SDN 032 Kualu yang berjumlah 26 orang siswa. Instrument penelitian yang digunakan adalah lembar observasi aktivitas siswa dan guru, tes kemampuan berpikir kritis siswa dan dokumentasi. Hasil penelitian menunjukkan bahwa penggunaan media pembelajaran dapat meningkatkan kemampuan berpikir kritis siswa sebesar 42,31\%. Peningkatan kemampuan berpikir kritis siswa dari pratindakan ke siklus I menunjukkan sebesar 23,07\% dan terjadi peningkatan dari siklus I ke siklus II sebesar 19,24\%.
\end{abstract}

Kata kunci: Media pembelajaran visual, Kemampuan berpikir kritis siswa, sekolah dasar.

\begin{abstract}
This study aims to determine the use of visual-based learning media in improving students' critical thinking skills in Mathematics subjects in grade IV SDN 032 Kualu. The method used in this research is Classroom Action Research (CAR). The CAR carried out occurred in two cycles. Each cycle uses four stages, including: planning stage, implementation stage, observation and reflection stage. The subjects of this study were the fourth grade students of SDN 032 Kualu, totaling 26 students. The research instrument used was student and teacher activity observation sheets, students' critical thinking ability tests and documentation. The results showed that the use of learning media can improve students' critical thinking skills by $42.31 \%$. The increase in students' critical thinking skills from pre-action to cycle I showed $23.07 \%$ and an increase from cycle I to cycle II was $19.24 \%$
\end{abstract}

Keywords: Visual learning media, students' critical thinking ability, elementary school. 



\section{Pendahuluan}

Berpikir merupakan suatu aktivitas yang selalu dilakukan oleh manusia, bahkan ketika mereka sedang tertidur. Kemampuan yang harus dimiliki peserta didik saat ini yaitu berpikir kritis. Florea dan Hurjui (2014: 566) mengatakan bahwa kemampuan berpikir kritis merupakan suatu proses berpikir yang aktif dan kompleks dengan mengakumulasikan informasi untuk memecahkan permasalahan.

Jika siswa sudah terbiasa memiliki keterampilan berpikir kritis dari sejak di bangku sekolah dasar, maka akan mempermudah siswa dalam jenjang pendidikan selanjutnya, yang sesuai dengan teori jean piaget pada tahap operasional konkreat (7-11 tahun) menyatakan bahwa "Pada masa ini, anak sudah mampu melakukan pengurutan dan klasifikasi terhadap objek maupun situasi tertentu. Kemampuan mengingat dan berpikir secara logis si Kecil pun makin meningkat. Ia mampu memahami konsep sebab-akibat secara rasional dan sistematis sehingga si Kecil mulai bisa belajar matematika dan membaca. Pada tahapan ini pula sifat "egosentris" si Kecil menghilang secara perlahan. Ia kini sudah mampu melihat suatu masalah atau kejadian dari sudut pandang orang lain. Matematika adalah salah satu mata pelajaran yang sangat penting dalam dunia pendidikan, karena pelajaran matematika dapat membuat peserta didik berfikir logis, rasional, kritis dan luas, pernyataan ini sejalan dengan tujuan pendidikan nasional, yaitu: Mempersiapkan anak didik agar mampu menghadapi perubahan dalam dunia yang senantiasa berubah ini, bertindak atas dasar pemikiran logis, rasional, kritis, dan agar anak didik mampu menggunakan matematika dalam kehidupan sehari-hari dan dalam mempelajari berbagai ilmu pengetahuan (Anika et al., 2018). Berdasarkan hasil observasi pada tanggal 14 dan 15 Juli 2021 kemampuan pikir kritis siswa kelas IV SDN 032 Kualu dapat dikatakan masih rendah keterampilan berpikir kritisnya dari segi aspek memberikan penjelasan sederhana, membangun keterampilan dasar, menyimpulkan, memberikan penjelasan lebih lanjut, dan mengatur strategi dan taktik.
Indikator kemampuan berpikir kritis siswa dari aspek memberikan penjelasan sederhana yang dilihat oleh peneliti masih tergolong rendah, yaitu kurangnya pemahaman peserta didik dalam menanggapi pertanyaan guru salah satunya karena kemampuan analisis pertanyaan pesrta didik masih rendah, sehingga jawaban dari peserta didik belum sesuai yang diinginkan. Indikator kemampuan berpikir kritis siswa dari aspek membangun keterampilan dasar yang dilihat oleh peneliti masih tergolong rendah, yaitu kurangnya kerjasama dalam mempertimbangkan hasil observasi dari pengamatan objek yang diperintahkan oleh guru sehingga kemampuan berpikir siswa tidak berkembang. Indikator kemampuan berpikir kritis siswa dari aspek menyimpulkan yang dilihat oleh peneliti masih tergolong rendah, yaitu peserta didik belum mampu menyimpulkan materi maupun menemukan konsep sendiri, berarti kemampuan menalar peserta didik masih rendah. Indikator kemampuan berpikir kritis siswa dari aspek memberikan penjelasan lanjut yang dilihat oleh peneliti masih tergolong rendah, yaitu kurangnya pemahaman siswa dalam mendefinisikan istilah dan mempertimbangkan definisi tersebut siswa belum mampu dalam memberikan penjelasan lanjut. Indikator kemampuan berpikir kritis siswa dari aspek mengatur strategi dan taktik yang dilihat oleh peneliti masih tergolong rendah, yaitu tidak ada peserta didik yang menyampaikan pendapat atau gagasan pada proses pembelajaran, sehingga tidak adanya interaksi dengan orang lain.

Berdasarkan masalah diatas, tindakan yang tepat untuk menangani masalah kurangnya keterampilan berpikir kritis adalah dengan menggunakan model pembelajaran berbasis visual karena Arsyad (2011:144) mengemukakan bahwa media berbasis visual adalah media yang hanya mengandalkan indra penglihatan. Media visual dapat memperlancar pemahaman peserta didik dan memperkuat ingatannya. Pada dasarnya belajar dengan menggunakan indra penglihatan dan indra lainnya akan memberikan keuntungan yang lebih optimal dalam proses pembelajaran. Siswa juga dapat bisa membiasakan menyimpulkan apa 
yang dipelajari dengan mengkomunikasikan sehingga pembelajaran terasa menyenangkan, menarik, semangat dalam belajar serta siswa bisa mengalami sendiri apa yang dipelajari dan bisa meningkatkan keterampilan berpikir kritis siswa. Adapun alasan yang paling mendasari peneliti memilih tindakan ini, karena pada langkahlangkah pendekatan ilmiah kompetensi yang dikembangkan diantaranya mengembangkan kreativitas, rasa ingin tahu, kemampuan merumuskan pertanyaan untuk membentuk pikiran kritis yang perlu untuk hidup cerdas dan belajar sepanjang hayat (kementerian pendidikan dan kebudayaan, 2014: 19).

Adapun tujuan penelitian tindakan kelas ini dilakukan sebagai berikut, untuk mengetahui bagaimana perencanaan pembelajaran menggunakan media visual terhadap peningkatan kemampuan berpikir kritis, untuk mengetahui bagaimana pelaksanaan pembelajaran menggunakan media visual terhadap peningkatan kemampuan berpikir kritis, untuk mengetahui bagaimana hasil pembelajaran menggunakan media visual terhadap peningkatan kemampuan berpikir kritis. Penelitian yang akan dilakukan ini diharapkan dapat memberikan beberapa manfaat, yaitu, memudahkan siswa dalam memahami pembelajaran tematik melalui penerapan media berbasis visual. Kemudian bagi guru sebagai media pilihan alternative dalam pembelajaran tematik. Sekolah: sebagai bahan masukan bagi pihak sekolah agar dapat digunakan dalam proses belajar mengajar.

\section{Metode}

Waktu penelitian ini dilaksanakan Juli 2021 pada Semester Ganjil atau Semester I tahun ajaran 2021/2022. Penelitian tindakan kelas ini yang menjadi subjek penelitian adalah siswa di kelas IV Sekolah Dasar Negeri 032 Kualu tahun ajaran 2021/2022 dengan jumlah sebanyak 26 siswa dengan jumlah lakilaki 15 siswa dan perempuan berjumlah 11 siswa. Penelitian yang diterapkan oleh peneliti adalah penelitian tindakan kelas. Rochiati (dalam Kusnandar, 2008: 46) penelitian Tindakan kelas termasuk penelitian kualitataif meskipun data yang dikumpulkan bisa saja besifat kuantitatif, dimana uraiannya bersifat deskriptif dalam bentuk kata-kata, peneliti merupakan instrument utama dalam pengumpulan data, proses sama pentingnya dengan produk. Penelitian Tindakan kelas merupakan suatu pencermatan terhadap kegiatan kegiatan belajar berupa sebuah Tindakan yang sengaja dimunculkan dan terjadi dalam sebuah kelas secara Bersama (Arikunto, dkk, 2014: 3). Arikunto (2013: 17) menjelaskan bahwa satu siklus PTK terdiri dari empat langkah yaitu. perencanaan, pelaksanaan, pengamatan, refleksi.

a. Perencanaan

Arikunto (2010: 17) mengemukakan bahwa perencanaan adalah langkah yang dilaksanakan oleh guruketika akan memulai tindakannya. Ada beberapa langkah yang dapat dilakukan dalam kegiatan ini yakni:

1) Membuat skenario pembelajaran yang merupakan bagian utama yang harus disiapkan oleh seorang guru dalam penulisan PTK. Hal inilah yang mendasari konsep PTK itu sendiri karena skenario pembelajaran mencerminkan upaya atau strategi yang dilakukan oleh guru dalam pembelajaran yang tertuang dalam serangkaian langkah-langkah sistematis.

2) Membuat lembaran observasi dimaksudkan guna mengukur keberhasilan penelitian dalam hal ini guru dalam melaksanakan proses pembelajaran sehingga diketahui kelebihan dan kekurangannya guna keperluan refleksi.

3) Mendesain alat evaluasi perlu diperhatikan bahwa alat evaluasi yang dibuat harus dapat mengukur apa yang seharusnya diukur. Untuk itu alat evaluasi tersebut perlu diuji cobakan terlebih dahulu diluar subjek penelitian.

\section{b. Pelaksanaan Tindakan}

Arikunto (2010: 18) memaparkan secara rinci hal-hal yang harus diperhatikan guru antara lain: 1) apakah ada kesesuaian antara pelaksanaan dengan perencanaan. 2) apakah proses tindakan yang dilakukan pada siswa cukup lancar. 3) bagaimanakah situasi proses tindakan. 4) apakah siswa-siswa 
melaksanakan dengan semangat dan, 4) bagaimanakah hasil keseluruhan dan tindakan itu. Dalam pelaksanaan tindakan ini dilakukan untuk meningkatkan kemampuan berpikir kritis pada siswa kelas IV. Dalam pelaksanaan penelitian tindakan kelas ini dirancang dalam dua siklus. Setiap siklus dua kali pertemuan. Pelaksanaan tindakan ini disesuaikan dengan RPP yang telah disusun sebelumnya. Langkah-langkah pelaksanaan tindakan atau kegiatan pembelajaran ini terdiri atas tiga tahap yaitu kegiatan awal, kegiatan inti, kegiatan akhir.

c. Observasi

$$
\text { Arikunto (2010: 19) }
$$

memaparkan tentang siapa yang melakukan pengamatan pada pelaksanaan tindakan sebagai berikut:

1) Pengamatan dilakukan oleh orang lain, yaitu pengamat yang diminta oleh peneliti untuk mengamati proses pelaksanaan tindakan yaitu mengamati apa yang dilakukan oleh guru, siswa maupun peristiwanya.

2) Pengamatan dilakukan oleh guru yang melaksanakan PTK. Dalam hal ni guru tersebut harus sanggup "ngrogoh sukmo", istilah bahawa jawa yaitu mencoba mengeluarkan jiwanya dari tubuh untuk mengamati dirinya, apa yang sedang dilakukan, sekaligus mengamati apa yang dilakukan oleh siswa dan bagaimana proses berlangsung.

d. Refleksi

Refleksi adalah langkah mengingat kembali kegiatan yang sudah lampau yang dilakukan oleh guru maupun siswa (Arikunto, 2010: 19) pada tahap ini hasil yang diperoleh pada tahap observasi akan dievaluasi dan dianalisis. Kemudian guru bersama pengamat dan juga peserta didik mengadakan refleksi diri dengan melihat data observasi, apakah kegiatan yang telah dilakukan dapat meningkatkan kualitas pembelajaran khususnya target yang akan ditingkatkan dalam penelitian misalnya hasil belajar, kemampuan berpikir kritis motivasi, kemampuan menulis, dan lain sebagainya. Pada dasarnya kegiatan refleksi adalah koreksi atas tindakan jadi peran pengamat dan peserta didik sangat membantu keberhasilan penelitian. Dari hasil refleksi bersama akan diperoleh kelemahan dan cara memperbaikinya guna diterapkan pada siklus berikutnya.

Teknik pengumpulan data adalah cara peneliti untuk mengumpulkan data-data yang digunakan dalam penelitian ini yaitu: teknik tes, teknik dokumentasi, dan teknik observasi. Penelitian ini menggunakan 2 teknis analisis data, yang pertama teknis analisis data hasil observasi, yang digunakan dalam penelitian ini adalah melakukan pengamatan terhadap siswa dan guru selama proses pembelajaran mengacu pada indikator kemampuan berpikir kritis yang meliputi memberikan penjelasan lebih lanjut, membangun keterampilan dasar, menyimpulkan, memberikan penjelasan lebih lanjut dan mengatur startegi dan teknik. Kemudian teknis analisis data tes dalam penelitian ini dinilai berdasarkan ketuntasan secara individu dan klasikal. Ketuntasan siswa secara individu dapat dilihat dari hasil kemampuan berpikir kritis siswa yang telah diperiksa guru dari hasil temuan pada setiap tindakan. Siswa dikatakan tuntas apabila nilainya sama dengan KKM atau lebih tinggi dari KKM yaitu 70 .

Diperoleh dengan perhitungan sebagai berikut:

KBSI $=\frac{\text { Jumlah Skor yang dicapai Siswa }}{\text { Skor Maksimum }} \times 100 \%$

(Yustisia, 2008:362)

Siswa dikatakan tuntas apabila telah memenuhi indikator keberhasilan yaitu tingkat penguasaan kemampuan berpikir kritisnya berkisar 80\%-89\% atau dinyatakan kritis. Menentukan ketuntasan klasikal rumus yang digunakan yaitu:

$$
\begin{aligned}
& \mathrm{KK}=\frac{\text { jumlah siswa yang tuntas }}{\text { jumlah seluruh siswa }} \times 100 \% \\
& \text { Keterangan: } \\
& \text { KK }=\text { Ketentuan Klasikal }
\end{aligned}
$$

Jika ketuntasan klasikal siswa telah mencapai $80 \%$ dari seluruh siswa, maka tingkat kemampuan berpikir kritis siswa secara klasika telah meningkat. Adapun kriteria tingkat kemampuan berpikir kritis 
pada pembelajaran Matematika dapat dilihat pada table 3.2

Tabel 3.2

Kriteria Tingkat Kemampuan Berpkir Kritis

\begin{tabular}{|c|c|}
\hline Rentang Skor & Keterangan \\
\hline $90-100$ & Sangat Krits \\
\hline $80-89$ & Kritis \\
\hline $70-79$ & Cukup Kritis \\
\hline $60-69$ & Kurang Kritis \\
\hline
\end{tabular}

Sumber: Wowo (dalam Citra, 2019)

\section{Hasil dan Pembahasan}

Penelitian ini dilakukan dengan dua siklus. Siklus I pertemuan pertama dan kedua dilakukan pada tanggal 16 \& 19 Juli 2021, kemudian untuk siklus II pertemuan pertama dan kedua dilakukan pada tanggal 23 \& 26 Juli 2021.

Berdasarkan kegiatan pratindakan pada mata pelajaran Matematika kelas IV SDN 032 Kualu dapat ditemukan bahwa kemampuan berpikir kritis siswa masih dikatakan rendah, hal ini ditunjukkan dengan adanya nilai rata-rata siswa yang mencapai 69,84 dengan persentase 42,31\% atau 11 orang siswa yang tuntas. Persentase yang tidak $57,69 \%$ atau 15 orang siswa yang tidak tuntas. Kemudian rata-rata siswa mencapai 69,84. Berdasarkan hasil tersebut dapat disimpulkan bahwa keberhasilan siswa belum mencapai $80 \%$. Untuk itu, perlu adanya tindakan siklus I untuk meningkatkan kemampuan berpikir kritis siswa dengan menggunakan media pembelajaran berbasis visual. Pada siklus I siswa yang tuntas secara keseluruhan 17 orang siswa atau dengan persentase $65,38 \%$. Dengan demikian pada siklus I keberhasilan siswa belum mencapai $80 \%$, hal ini ditunjukkan dengan peningkatan dari pratindakan ke siklus I yang awalnya dengan rata-rata 69,84 menjadi 77,84 (naik 8 angka), dengan persentase yang awalnya $42,31 \%$ menjadi $65,38 \%$ (naik 23,07\%), dengan berjumlah 11 orang siswa yang tuntas menjadi 17 orang siswa yang tuntas (naik 6 orang siswa). Pada siklus II siswa yang tuntas secara keseluruhan berjumlah 22 orang siswa atau dengan persentase $84,62 \%$. Dengan demikian pada siklus II keberhasilan siswa sudah mencapai $80 \%$, hal ini ditunjukkan dengan peningkatan dari siklus I ke siklus II yang awalnya dengan rata-rata 77,84 menjadi 88,30 (naik 10,46), dengan persentase yang awalnya 65,38\% menjadi 84,62\% (naik 19,24\%), dengan berjumlah 17 orang siswa yang tuntas menjadi 22 orang siswa yang tuntas (naik 5 orang siswa). Untuk itu, peneliti tidak perlu melakukan siklus berikutnya, karena sudah jelas kemampuan berpikir kritis siswa yang diperoleh telah meningkat.

Peningkatan hasil tes kemampuan berpikir kritis siswa dari sebelum tindakan hingga siklus II dapat dilihat pada tabel berikut:

Tabel 4

\begin{tabular}{|c|c|c|c|}
\hline $\begin{array}{c}\text { Keteranga } \\
\mathrm{n}\end{array}$ & $\begin{array}{c}\text { Pra } \\
\text { Tindaka } \\
\mathrm{n}\end{array}$ & Siklus I & Siklus II \\
\hline Rata-Rata & 69,84 & 77,84 & 88,30 \\
\hline $\begin{array}{c}\text { Jumlah } \\
\text { yang } \\
\text { Tuntas }\end{array}$ & 11 Siswa & 17 Siswa & 22 Siswa \\
\hline $\begin{array}{c}\text { Persentase } \\
\text { Ketuntasa } \\
\mathrm{n}\end{array}$ & $\begin{array}{c}(42,31 \% \\
\text { n }\end{array}$ & $\begin{array}{c}(65,38 \% \\
)\end{array}$ & $\begin{array}{c}(84,62 \% \\
)\end{array}$ \\
\hline
\end{tabular}

\section{Simpulan}

Berdasarkan hasil penelitian yang telah dilaksanakan dapat disimpulkan bahwa penggunaan media pembelajarran berbasis visual dapat meningkatkan kemampuan berpikir kritis siswa dari pratindakan ke siklus I yang awalnya dengan rata-rata 69,84 menjadi 77,84 (naik 8 angka), dengan persentase yang awalnya $42,31 \%$ menjadi 65,38\% (naik 23,07\%), dengan berjumlah 11 orang siswa yang tuntas menjadi 17 orang siswa yang tuntas (naik 6 orang siswa).

Pada peningkatan siklus I ke siklus II yang awalnya dengan rata-rata 77,84 menjadi 88,30 (naik 10,46), dengan persentase yang awalnya $65,38 \%$ menjadi 84,62\% (naik 19,24\%), dengan berjumlah 17 orang siswa yang tuntas menjadi 22 orang siswa yang tuntas (naik 5 orang siswa).

Jadi secara keseluruhan media pembelajaran berbasis visual dari pratindakan ke siklus II dapat meningkatkan kemampuan berpikir kritis siswa yang awalnya dengan rata-rata 69,84 menjadi 
88,30 (naik 18,46), dengan persentase yang awalnya $42,31 \%$ menjadi $84,62 \%$ (naik $42,31 \%$ ), dengan berjumlah 11 orang siswa yang tuntas menjadi 22 orang siswa yang tuntas (naik 11 orang siswa).

\section{Daftar Pustaka}

[1] Abdul Majid. (2014). Strategi Pembelajaran. Bandung: PT Remaja Rosdakarya.

[2] Affandy, H., Aminah, N. S., \& Supriyanto, A. (2019). Analisis Keterampilan Berpikir Kritis Siswa Pada Materi Fluida Dinamis Di SMA Batik 2 Surakarta. Jurnal Materi Dan Pembelajaran Fisika (JMPF), 9(1), 2533.

https://jurnal.uns.ac.id/impf/article /view/31608

[3] Anika, E., Hidayat, A., \& Ediputra, K. (2018). Kemampuan Pemahaman Konsep Matematis Siswa Kelas VIII melalui Model Pembelajaran Kooperatif Tipe Teams Games Tournament. Jurnal Cendekia: Jurnal Pendidikan Matematika, 2(2), 101110.

[4] Arikunto, S (2010), Penelitian Tindakan Kelas, Jakarta: PT Bumi Aksara.

[5] Arikunto, Suharsimi dkk. (2014). Penelitian Tindakan Kelas. Jakarta: Bumi Aksara.

[6] Arsyad, Azhar. (2016). Media Pembelajaran. Jakarta: Raja Grafindo Persada.

[7] Barrimi, M., Aalouane, R., Aarab, C., Hafidi, H., Baybay, H., Soughi, M., Tachfouti, N., Nejjari, C., Mernissi, F. Z., Rammouz, I., \& McKenzie, R. B. (2013). No Title No Title. Encephale, 53(1), 59-65. http://dx.doi.org/10.1016/j.encep.2 012.03 .001$.

[8] Fadhilaturrahmi, F. (2019). Pengaruh Pembelajaran Kooperatif Tipe Gi Terhadap Peningkatan Kemampuan Koneksi Matematik Siswa Sekolah Dasar. Edukatif: Jurnal Ilmu Pendidikan, 1(1), 4355.https://doi.org/10.31004/edukat if.v1i1.5.
[9] Hamdani. (2011). Strategi Pembelajaran. Bandung. CV Pustaka Setia.

[10] Hartono. (2010). Analisis Item Instrumen, Zanafa Publishing, Bandung.

[11] Hidayah, R. Salimi, M. \& Susiani, T.S. (2017). Critical Thinking Skill: Konsep dan Indikator Penilaian. Jurnal Taman Cendekia. 1(2): 127133.

[12] Jensen, Eric. (2011). Pembelajaran Berbasis Otak (Edisi Kedua). Jakarta: PT Indeks Permata Puri Media. 